\title{
Oclusión de óxidos cromoforos mediante métodos Sol-Gel: Aplicación a la síntesis de rojo Hematita-Sílice
}

\author{
J.B. VICENT, M. LLUSAR, J. BADENES, M.A. TENA, M. VICENTE Y G. MONRÓS. \\ Dpto. Química Inorgànica i Orgànica, Universitat Jaume I, Ap. Correos 224, 12080-Castellón.
}

\begin{abstract}
En los pigmentos heteromórficos la partícula de cromóforo es ocluida en una matriz encapsuladora estable tanto termicamente como frente a los vidriados. El compuesto cromóforo ocluido y la matriz no coloreada son insolubles. En este trabajo se analiza los diferentes mecanismos de formación de estos pigmentos heteromórficos y se estudia la oclusión de hematita en sílice mediante métodos sol-gel acuoso. El pigmento sigue un mecanismo de sinterización-crecimiento cristalino por lo que es muy importante controlar el momento de nucleación y la velocidad de crecimiento de las partículas de hematita en el seno de la matriz.
\end{abstract}

\section{Occlusion of chromophore oxides by Sol-Gel methods: Application to the synthesis of hematite-silica red pigments}

\begin{abstract}
Heteromorphic pigments present the chromophore particle occluded in an encapsulating matrix which is thermally stable and insoluble in glazes. The occluded chromophore compound is also insoluble in the host matrix. In this work the mechanisms of formation of this type of pigments are analyzed and the occlusion of hematite into silica matrix is discussed. The formation of this hematite-silica red pigment follows a sintering-coarsening mechanism, and, consequently, the control of both hematite particles nucleation and their crystal growth results to be decisive to obtain a good coloring effectiveness.
\end{abstract}

Key words: Pigment, Oclussion, Sol-Gel, Silica.

\section{INTRODUCCIÓN}

En la producción de materiales cerámicos los iones colorantes pueden ejercer su acción al disolverse en el material a colorear, pasta o vidriado, tal y como ocurre con los óxidos de metales de transición y sus sales. También pueden reaccionar en el horno produciendo partículas colorantes, como en el caso de la dispersión coloidal de cobre metálico en los rojos "Sang de boeuf" obtenidos por reducción de sales de $\mathrm{Cu}(\mathrm{I})$, precedida de una etapa oxidante cuya finalidad es la de controlar el tamaño de las partículas coloidales, ya que si éste es pequeño da colores amarillos en lugar de rojos (1). Las dos posibilidades anteriores resultan industrialmente poco recomendables dada la dificultad de controlar los procesos de disolución y reducción con el fin de obtener una buena reproducibilidad en la producción. En la industria cerámica se utilizan pigmentos calcinados o sintéticos en los que el cromóforo se ha incorporado por reacción en la calcinación a una red huésped de suficiente estabilidad térmica y resistencia a la disolución frente a los vidriados (fritas y/o adyuvantes de la sinterización).

Desde el punto de vista del método de incorporación del cromóforo a la red huésped, podemos considerar tres grandes tipos de pigmentos calcinados.

(I) Pigmentos estructurales: el cromóforo se integra estructu-

\section{INTRODUCCION}

In the production of colored ceramic materials the coloring ions can play their role by being solved in the material which we intend to color, ceramic body or glaze, as it occurs with transition metal oxides and its related salts. The coloring effect can also be provided by reacting the coloring ions in the furnace to obtain the appropriate coloring particles, as is the case of the dispersion of colloidal metallic $\mathrm{Cu}$ in the so called "sang de boeuf" red colors. These red colors are obtained by reducing the appropriate $\mathrm{Cu}(\mathrm{I})$ salt, with a previous oxidant stage in order to control the size of the colloidal particles involved: should these particles be too small, yellow colors instead of reds are produced (1).

Both of these alternatives do not appear to be recommendable in the industrial manufacture, since the solution and/ or reduction processes involved are pretty difficult to control and a good reproducibility must always be guaranteed in the industrial production. Instead of these procedures, calcined or synthetic pigments are being widely used in the ceramic industry; in these calcined pigments, the chromophore agent has already been incorporated into an appropriate host lattice during the calcine stage by some kind of reaction. Of cour- 
ralmente en una red cristalina de forma estequiométrica. Es el caso de la incorporación de cromo en la red del granate uvarovita $\mathrm{Ca}_{3} \mathrm{Cr}_{2} \mathrm{Si}_{3} \mathrm{O}_{12}(2)$.

(II) Disoluciones sólidas: El cromóforo se incorpora a la red huésped sustituyendo a uno de los iones estructurales. Es el caso de la incorporación de $\mathrm{V}(\mathrm{IV})$ o $\mathrm{Pr}(\mathrm{IV})$ en la red de $\mathrm{ZrSiO}_{4}$ en el turquesa de vanadio-circón y el amarillo de praseodimiocircón respectivamente $(3,4)$.

(III) Pigmentos mordientes, también denominados pigmentos de adsorción, en este caso el cromóforo en forma de partícula coloidal es adsorbida por la estructura huésped por intensas fuerzas de quimiadsorción (5).

Los ejemplos más ampliamente considerados como mordientes en la literatura son los de $\mathrm{V}_{2} \mathrm{O}_{5}$ en circona (amarillo de circona-vanadio) y el de $\mathrm{Cr}_{2} \mathrm{O}_{3}$ en la esfena $\mathrm{CaSnSiO}_{5}$ (rosa de cromo-estaño) (6)

(IV) Pigmentos encapsulados, de oclusión o heteromórficos: la partícula de cromóforo es ocluida en una matriz encapsuladora estable termica y frente a los vidriados. El compuesto cromóforo ocluido y la matriz no coloreada son insolubles, no siendo importante el mecanismo de disolución sólida del primero en el segundo, asimismo el tamaño de la partícula ocluida es suficientemente grande (coloidal usualmente) siendo la unidad cromática del pigmento.

El objetivo de este trabajo es analizar los diferentes mecanismos de formación de estos pigmentos heteromórficos y estudiar la oclusión de hematita en sílice.

\subsection{Mecanismos de oclusión.}

A partir de lo expuesto anteriormente, en los pigmentos encapsulados, las partículas responsables del color son cristales nanométricos ocluidos durante el proceso de sinterización de la matriz.

La producción de este tipo de pigmentos está directamente ligada con el proceso de sinterización y/o cristalización de la matriz, que debe estar en adecuada sincronía con el proceso de nucleación-crecimiento de la fase cromófora ocluida, no interfiriendo ambos procesos.

En este sentido los métodos de control de estas dos etapas, son fundamentales con el fin de conseguir que en el mismo intervalo de temperaturas, crezca la partícula cromófora de forma adecuada en localización y tamaño para que pueda ser atrapada por las partículas de la matriz en su proceso de sinterización. En la literatura se manejan dos mecanismos de oclusión.

\subsubsection{MECANISMO DE CRISTALIZACIÓN-SINTERIZACIÓN.}

El color de los pigmentos basados en la disolución sólida de cristales hexagonales de CdS y CdSe varía desde el amarillo al rojo oscuro dependiendo de la cantidad de Se presente en la disolución sólida. Estos pigmentos son fácilmente diluidos por los vidriados y son sensibles tanto a la atmósfera como a la temperatura de calcinación, además son materiales altamente tóxicos y peligrosos. El pigmento requiere un vidriado diseñado especialmente para él: un vidrio borosilicato con baja proporción de alcalinos y conteniendo un porcentaje no muy alto de óxido de cadmio que retarda el ataque del vidriado sobre el pigmento.

Lambíes y Rincón plantean un mecanismo de cristalizaciónsinterización para la oclusión de cristales de disolución sólida se, the host lattice must have and adequate thermal stability and must remain insoluble withstanding the aggressive action of the glazes (ceramic frits and/or sintering additives) in which they are formulated.

With regard to the way in which the chromophore agent can be incorporated in the host lattice, four main categories of calcined pigments can be distinguished:

(I) Structural pigments: the chromophore is stoichiometrycally incorporated in a host crystalline lattice. Such is the case of the $\mathrm{Cr}$ being present in the lattice of the green uvarovite garnet, $\mathrm{Ca}_{3} \mathrm{Cr}_{2} \mathrm{Si}_{3} \mathrm{O}_{12}$ (2).

(II) Solid Solutions: the chromophore enters into the host lattice by substituting for one of the structural ions. Such is the case of $\mathrm{V}(\mathrm{IV})$ or $\mathrm{Pr}(\mathrm{IV})$ in the $\mathrm{ZrSiO}_{4}$ lattice to give the vanadium-zircon blue and the praseodimium-zircon yellow, respectively $(3,4)$.

(III) Mordant Pigments (also known as adsorption pigments): in this case the chromophore can be found as a colloidal particle adsorbed by the host structure as a result of the intense chemiadsorption forces (5). Two examples of pigments widely considered as being mordant are those of $\mathrm{V}_{2} \mathrm{O}_{5}$ in zirconia (vanadium-zirconia yellows) and $\mathrm{Cr}_{2} \mathrm{O}_{3}$ in sphene $\mathrm{CaSnSiO}_{5}$ (tin-chromium pinks) (6).

(IV) Encapsulated, Inclusion, Occlusion or Heteromorphic Pigments: the chromophore particle is included, occluded or entrapped in an encapsulating matrix which is thermally stable and withstands the action of glazes. Both the occluded chromophore compound and the uncolored matrix are insoluble, and the possible solid solution mechanism of the former in the later can be discarded. In addition, the size of occluded particles is large enough (usually colloidal) to become the chromatic unit of the pigment.

The aim of this paper is to analyze the different mechanisms of formation of these heteromorphic pigments and also to study the particular case of the occlusion of hematite in silica.

\subsection{Occlusion mechanisms}

From the above discussion, the particles responsible for the color in encapsulated pigments can be considered as nanometric crystals occluded during the matrix synthering process.

Therefore, the production of this kind of pigments must strongly depend on the matrix syntering and/or coarsening process, which must take place with a good synchronism with that of nucleation and growing of occluded particles, without any interference.

In this respect, the methods which allow us to control both processes become of the utmost importance with the aim to reach in the same temperature range an optimal or appropriate growth of the chromophore particle, regarding not only to the size but also to the localization, so that they can be efficiently trapped by the matrix particles which are simultaneously syntering. Two different occlusion mechanisms are discussed in the literature.

\subsubsection{CRYSTALLIZATION-SYNTERING MECHANISM.}

The color of pigments based on the solid solution of CdS and CdSe hexagonal crystals goes from yellow to dark red depending on the quantity of Se being present in the solid 
$\mathrm{Cd}\left(\mathrm{S}_{\mathrm{x}} \mathrm{Se}_{1-\mathrm{x}}\right)$ en red de circón (7). Con el fin de mejorar la estabilidad del color se han desarrollado los métodos de encapsulado en circón $(8,9)$. La eficiencia de encapsulado es baja y no quedan resueltos del todo los problemas de estabilidad térmica y química: resultan ser altamente sensibles a la temperatura y al vidriado (sólo pueden ser utilizados con garantía con vidriados cocidos por debajo de $900^{\circ} \mathrm{C}$ ). Son altamente tóxicos, tanto en su producción como en su consumo ya que son extremadamente sensibles al ataque químico.

El mecanismo de formación del pigmento ocluido tiene las siguientes etapas:

1) Formación de los cristales huésped de circón, de $\mathrm{Cd}\left(\mathrm{S}_{x} \mathrm{Se}_{1-\mathrm{x}}\right)$ y fases líquidas.

2) Sinterización del circón y oclusión del $\mathrm{Cd}\left(\mathrm{S}_{x} \mathrm{Se}_{1-\mathrm{x}}\right)$.

Los cristales de $\mathrm{Cd}\left(\mathrm{S}_{\mathrm{x}} \mathrm{Se}_{1-\mathrm{x}}\right)$ se pueden obtener previamente por coprecipitación del mismo al añadir una disolución se sulfoseleniuro de sodio sobre una disolución de una sal de cadmio o de una suspensión de una mezcla de una sal insoluble de cadmio (carbonato, hidróxido u óxido) y una soluble (nitrato o sulfato). También pueden obtenerse estos cristales in situ por reacción de selenio con CdS o de la mezcla azufre y selenio con $\mathrm{CdCO}_{3}$ a temperaturas entre $450-600^{\circ} \mathrm{C}$ según los procesos (10).

La presencia de las fases vítreas de $\mathrm{Li}_{2} \mathrm{SiO}_{3}\left(\mathrm{Na}_{2} \mathrm{SiO}_{3}\right.$ en el caso de emplear $\mathrm{NaF}$ como mineralizador en lugar de $\mathrm{LiF}$ ), producen una reordenación de las partículas de circón neoformadas de pequeño tamaño que crecen tal y como propone la teoría clásica de la sinterización, a través de un mecanismo de disolución y precipitación, contribuyendo el transporte superficial al enlace interpartículas. Si en el proceso, uno de los pequeños microcristales neoformados de $\mathrm{Cd}\left(\mathrm{S}_{x} \mathrm{Se}_{1-\mathrm{x}}\right)$ queda atrapado en los frentes de sinterización se produce la oclusión efectiva del mismo de acuerdo con la secuencia de la Fig. 1 modificada de la recogida por Lambíes y Rincón en (7).

La eficiencia de la oclusión es baja de modo que sólo los cristales de $\mathrm{Cd}\left(\mathrm{S}_{\mathrm{x}} \mathrm{Se}_{1-\mathrm{x}}\right)$ muy pequeños son susceptibles de ser atrapados por los granos de circón.

\subsubsection{MECANISMO DE SINTERIZACIÓN-CRECIMIENTO CRISTALINO.}

Para otros pigmentos tales como el coral de hierro en circón o de hematita en sílice, el mecanismo anterior no parece posible dado que el pigmento se puede conseguir a partir de la propia hematita eligiendo el mineralizador adecuado. La cinética de formación de este pigmento ha sido estudiada por
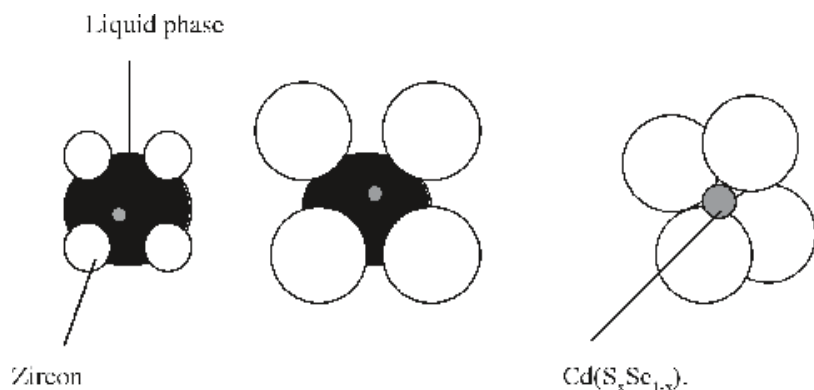

Figura 1: Mecanismo de cristalización-sinterización (modificada de Lambíes y rincón (7))

Figure 1: Crystallization-synthering mechanism (modification from that of Lambies and Rincón (7)) solution. Such pigments are quite easily diluted by the glazes and are also sensitive to both firing atmosphere and temperature. Therefore, a specially tailored glaze is required for them: a low alkaline borosilicate glaze containing a little cadmium oxide percentage to hinder or delay as much as possible the pigment attack by the glaze. Furthermore, these pigments are considered to be highly hazardous and dangerous materials.

Lambies and Rincón suggest a crystallization-synthering mechanism for the occlusion of $\mathrm{Cd}\left(\mathrm{S}_{\mathrm{x}} \mathrm{Se}_{1-\mathrm{x}}\right)$ solid solution crystals in a zircon lattice (7). In order to improve the pigment stability the encapsulation methods in zircon have been developed $(8,9)$. However, the encapsulation efficiency is still rather low and the problems of thermal and chemical stability remain not fully solved: they result to be highly sensitive to the temperature and to the glaze (they can only be used with a good performance in glazes fired below cone 1), and they are highly toxic, not only during the manufacture stages but also in the consume, since they are extremely sensitive to chemical attack.

The mechanism for the formation of the pigment would follow the following steps:

1) Formation of zircon host crystals, and that of $\mathrm{Cd}\left(\mathrm{S}_{\mathrm{x}} \mathrm{Se}_{1-\mathrm{x}}\right)$ and liquid phases.

2) Zircon synthering and $\mathrm{Cd}\left(\mathrm{S}_{x} \mathrm{Se}_{1-\mathrm{x}}\right)$ occlusion.

The $\mathrm{Cd}\left(\mathrm{S}_{\mathrm{x}} \mathrm{Se}_{1-\mathrm{x}}\right)$ crystals can previously be prepared by coprecipitation just adding a sodium sulphoselenide solution to a cadmium salt solution or to a suspension of a mixture between an insoluble cadmium salt (carbonate, hydroxide or oxide) and a soluble one (nitrate or sulphate). The crystals can also be obtained "in situ" by reacting Se with CdS or a mixture of $\mathrm{S}$ and Se with $\mathrm{CdCO}_{3}$ at temperatures ranging between $450-600^{\circ} \mathrm{C}$, depending on the processes involved (10).

The presence of $\mathrm{Li}_{2} \mathrm{SiO}_{3}$ vitreous phases $\left(\mathrm{Na}_{2} \mathrm{SiO}_{3}\right.$ if $\mathrm{NaF}$ is employed as mineralizer instead of $\mathrm{LiF}$ ) produce a rearrangement of the small-sized, neoformed zircon particles, which grow following the classical syntering theory based on a solution-precipitation mechanism with a contribution of surface transport to the interparticular (among particles) bonding. Should one of the small neoformed $\mathrm{Cd}\left(\mathrm{S}_{\mathrm{x}} \mathrm{Se}_{1-\mathrm{x}}\right)$ crystals be trapped in the syntering fronts during this process, therefore an effective occlusion of such crystal is to be expected, according to the sequence presented in Figure 1, which is a modification of that proposed by Lambies and Rincón in (7).

In this pigment, the occlusion efficiency is low, and, consequently, only those crystals of $\mathrm{Cd}\left(\mathrm{S}_{\mathrm{x}} \mathrm{Se}_{1-\mathrm{x}}\right)$ sufficiently small are susceptible of being trapped by the zircon grains.

\subsubsection{SYNTERING-COARSENING MECHANISM.}

When other pigments are considered, such as the iron-zircon coral or the hematite-silica red, the previous mechanism does not seem to fit accurately, since the pigment can be obtained from the hematite itself by choosing the appropriate mineralizer. The kinetics for the formation of the iron-zircon coral has been studied by Eppler (11) finding out that the experimental dates, obtained with the "inert marker" technique, follow the nucleation model only for low transformation degrees.

In the studies of J. Lahuerta (12) about this color, in which the encapsulated nature of the pigment is always accepted as a valid hypothesis, a review of the employment of different 
Eppler (11) encontrando que los datos experimentales, obtenidos por la técnica del marcador inerte, siguen el modelo de nucleación para grados de transformación bajos.

Los trabajos de J. Lahuerta (12) en este pigmento parten de una hipótesis encapsulada del pigmento, hacen un repaso al empleo de mineralizadores en el sistema $\left(\mathrm{Na}_{2} \mathrm{SiF}_{6}+\mathrm{Na}_{3} \mathrm{AlF}_{6}, \quad \mathrm{BaF}_{2}+\mathrm{MgF}_{2}\right)$, utilizando siempre hematita como fuente de hierro. Este autor concluye que el mecanismo de formación del pigmento resulta tanto de la formación de la microestructura protectora como de la coloración adecuada de las partículas de hematita. Asimismo P. Tartaj y otros (13) estudian la formación del pigmento Figura 2. Oclusión de hematita en circón por modelo de difua partir de la pirólisis de aerosoles

obtenidos por nebulización de diso-Figure 2. Hematite occlusion in zircon by a synthering-coarseluciones en metanol de etóxido dening model

silicio, oxicloruro de circonio y nitrato de hierro. Estos polvos están

integrados por partículas esféricas muy regulares de $0,1 \mathrm{~mm}$. Según estos autores, se produce la formación de la disolución sólida de $\mathrm{Fe}^{3+}$ en circona tetragonal, constatando la presencia de finas partículas de $\gamma \mathrm{Fe}_{2} \mathrm{O}_{3}$ en el sistema que podrían explicar las dificultades de producción regular de este color.

M. LLusar (14), utilizando métodos sol-gel en la síntesis del color, propone como modelo general que partiendo de la circona con una fina partícula de hematita en su superficie, reacciona con la sílice, según un mecanismo binario de difusión, para dar circón, que sinteriza con otros granos encapsulando la partícula de hematita que permaneció en su sitio, si bien pudo crecer durante el proceso anterior por crecimiento cristalino difusivo. Este modelo se esquematiza en la Fig. 2.

La principal diferencia entre este modelo y el anterior es que se considera que transcurren simultáneamente los procesos de formación de cristales (huésped y anfitrión), sinterización y oclusión, explicándose que la cinética de reacción siga el modelo de nucleación-crecimiento observado por Eppler (11). En favor de este modelo estaría el hecho ampliamente constatado en la literatura de que no se puede obtener el pigmento coral de hierro a partir de circón directamente mezclado con mineralizadores y el precursor de hierro. Si el problema fuera sólo de unos cristales de circón sinterizando y encapsulando cristales de hematita, debería poder obtenerse el pigmento a partir de circón, esto sugiere la simultaneidad de los procesos de cristalización-sinterización-oclusión. En ambos casos, las presencia de fases líquidas generadas por los mineralizadores es fundamental para desarrollar a velocidades suficientes los procesos difusivos involucrados.

\subsection{Aplicación de métodos sol-gel.}

La técnica sol-gel nos permite alcanzar desde las unidades discretas $(0,2 \mu \mathrm{m})$ que permanecen dispersas en un líquido (lo que define al sol), una red tridimensional sólida que se extiende a toda la matriz líquida, que sería el gel. Antes de la gelificación podemos medir viscosidades, después de producirse mineralizers $\left(\mathrm{Na}_{2} \mathrm{SiF}_{6}+\mathrm{Na}_{3} \mathrm{AlF}_{6^{\prime}}\right.$ $\mathrm{BaF}_{2}+\mathrm{MgF}_{2}$ ) using hematite as $\mathrm{Fe}$ precursor is made. This author concludes that a satisfactory coloring performance of the pigment is not only due to an adequate development of the protecting microstructure but also due to the hematite particles having the appropriate color. On the other hand, P. Tartaj et alter (13) study the pigment formation by pyrolysis of aerosols produced by nebulization of methanolic solutions of silicon ethoxide, zirconium oxychloride, and iron nitrate. These powders consist of very regular spherical particles with an average size of $0.1 \mathrm{~mm}$. According to these authors, a solid solution between $\mathrm{Fe}^{3+}$ cations and tetragonal zirconia is formed, and the presence of fine $\mathrm{gFe}_{2} \mathrm{O}_{3}$ particles can also be observed in the system, which could explain the difficulties encountered by the industry to obtain a regular production of this pigment

M. Llusar (14) suggests another general model for the formation of the pigment from both ceramic and sol-gel methods. This model considers that zirconia with a finer hematite particle on its surface can react with the silica present in the vicinity through a binary diffusion mechanism to give rise to zircon, which then synterises with other grains encapsulating the hematite. This hematite could have remained in its place or have grown following a "diffusive coarsening" process while zircon was being formed. This model is represented in Figure 2.

The principal difference between this model and the previous one is that now the processes of crystal formation (both host and guest crystals), syntering and occlusion, are considered to take place simultaneously, and the kinetics of the reaction is considered to follow the nucleation-coarsening model observed by Eppler (11). The fact that the iron coral pigment cannot be obtained by reacting directly a mixture of zircon, mineralizers, and the Fe precursor, which is widely confirmed in the literature, could corroborate this model. If it only were a matter of the zircon crystals being syntering and encapsulating the smaller hematite crystals, therefore it would be able for us to obtain the pigment directly from zircon, but such is not the case, which suggests that the crystallization-syntering-occlusion processes occur simultaneously. Anyway, in both cases the presence of fluid phases provided by the mineralizers appears to be of the utmost importance in order to develop with the appropriate celerity the involved diffusion processes.

\subsection{Aplication of sol-gel methods.}

The sol-gel technique let us obtain from discrete units $(0,2 \mu \mathrm{m})$ dispersed in a liquid media (known as a $s o l)$ a solid 3-dimensional network which extends to the whole liquid matrix (known as a gel). Viscosities can be measured before the gelling point, while elastic properties appear after gela- 
ésta aparecen las propiedades elásticas. Una vez obtenido el gel, éste debe ser secado y tratado mecánica y térmicamente según lo que se pretenda obtener.

Podemos distinguir entre sol-gel en fase acuosa (precursores ionizados) o en fase orgánica a partir de alcóxidos (precursores no ionizados). En los dos casos el proceso de obtención del gel comporta el desarrollo de unas etapas sucesivas de: Hidrólisis $\rightarrow$ Polimerización $\rightarrow$ Nucleación $\rightarrow$ Crecimiento $\rightarrow$ Aglomeración (15).

Todas las etapas son importantes a la hora de diseñar el gel final.

\subsubsection{HIDRÓLISIS-POLIMERIZACIÓN.}

En esta etapa se formula el tamaño de las "partículas primarias" del sólido, conformadas por cadenas químicas polinucleares de los cationes, unidos por puentes químicos oxo, hidroxo, aqua o cualquier otro anión puente $\mathrm{A}^{-}$. La formulación formal de estas reacciones, muy complejas en la realidad, puede esquematizarse de acuerdo con las expresiones utilizadas por Pierre (16):

Gel Coloidal (acuoso)

hidrólisis: $\mathrm{M}\left(\mathrm{H}_{2} \mathrm{O}\right)_{n}{ }^{\mathrm{z}+}+\mathrm{OH}^{-} \rightarrow \mathrm{M}\left(\mathrm{H}_{2} \mathrm{O}\right)_{\mathrm{n}-1}(\mathrm{OH})^{(\mathrm{z}-1)+}+\mathrm{H}^{+}$. polimerización: $\mathrm{xM}\left(\mathrm{H}_{2} \mathrm{O}\right)_{\mathrm{n}}{ }^{\mathrm{z}}+\mathrm{yOH}^{-}+\mathrm{aA}^{-} \rightarrow \mathrm{M}_{\mathrm{x}} \mathrm{O}_{\mathrm{u}}\left(\mathrm{H}_{2} \mathrm{O}\right)_{\mathrm{n}}(\mathrm{OH})$ $y-2 \mathrm{u}_{\mathrm{a}} \mathrm{a}^{(\mathrm{xz}-\mathrm{y}-\mathrm{a})++}+(\mathrm{xn}+\mathrm{u}-2 \mathrm{n}) \mathrm{H}_{2} \mathrm{O}$.

Gel Polimérico (alcóxidos)

hidrólisis: $\mathrm{M}(\mathrm{OR}) \mathrm{n}+\mathrm{xH}_{2} \mathrm{O} \rightarrow \mathrm{M}(\mathrm{OH})_{\mathrm{x}}(\mathrm{OR})_{\mathrm{n}-\mathrm{x}}+\mathrm{xROH}$. polimerización: $-\mathrm{M}-\mathrm{OH}+\mathrm{HO}-\mathrm{M} \rightarrow-\mathrm{M}-\mathrm{O}-\mathrm{M}-+\mathrm{H}_{2} \mathrm{O}$

\subsubsection{NUCLEACIÓN-CRECIMIENTO.}

Se diseña el tamaño de partícula y la distribución de tamaños del sólido neoformado. En general los métodos sol-gel evitan los procesos de nucleación heterogénea, que dependen de inclusiones extrañas (impurezas o agentes de nucleación introducidos de forma controlada) o inesperados productos primarios de hidrólisis. La nucleación homogénea permite una mejor hechura de partícula y una distribución monodispersa, bimodal... de las partículas de sol prediseñadas.

\subsubsection{FASE AGLOMERATIVA ENTRE LAS PARTÍCULAS.}

En esta etapa se conforma la estructura del sólido final. En esta fase de reunión de partículas de forma ordenada (gel) o no (precipitado), se ponen en juego diferentes fuerzas según la naturaleza de las sustancias presentes.

En el caso de coloides acuosos la teoría DLVO (Dejaguin, Landau, Verwey, Overbeek) explica bien los fenómenos de coagulación y engrosamiento del coágulo o floculación atendiendo a fenómenos electrostáticos $(17,18,19)$. En cambio en coloides orgánicos o de coloides acuosos protegidos con orgánicos $(20,3)$, los fenómenos estéricos son la fuerza conductora de formación del gel.

De acuerdo con lo anteriormente expuesto, dentro de la estrategia de síntesis de pigmentos heteromórficos, el procesado sol-gel puede utilizarse en dos variantes:

(I) Dada la alta reactividad del gel en procesos activados por nucleación heterogénea, pueden utilizarse los geles añadiendo los nucleantes apropiados para obtener a bajas temperaturas los cristales necesarios. Sería el caso de los pigmentos rojos de tion. Once gelation has occurred, the gel must be conveniently dried and mechanically and thermally treated, depending on what is intended to be obtained.

We can distinguish between those sol-gel processes carried out in an aqueous media (ionized precursors) and those obtained in an organic media using alkoxides (non-ionized precursors). Both of them involve the obtention of the gel after a series of successive steps (15): Hydrolysis $\rightarrow$ Polymerization $\rightarrow$ Nucleation $\rightarrow$ Crystal line Growth $\rightarrow$ Agglomeration

Each and every of these steps are relevant when tailoring the desired final gel:

\subsubsection{HYDROLYSIS-POLYMERIZATION}

At this stage, the size of the "primary particles" is designed, which are conformed by cationic polinuclear chemical chains bonded by means of oxo, hydroxo or aqua chemical bridges, or by any other $\mathrm{A}^{-}$bridging anion. A general formulation for such reactions is difficult to express, but it can be schematized according to the expressions used by Pierre (16):

Colloidal Gel (aqueous)

hydrolysis: $\mathrm{M}\left(\mathrm{H}_{2} \mathrm{O}\right)_{\mathrm{n}}{ }^{\mathrm{z}}+\mathrm{OH}^{-} \rightarrow \mathrm{M}\left(\mathrm{H}_{2} \mathrm{O}\right)_{\mathrm{n}-1}(\mathrm{OH})^{(\mathrm{z}-1)+}+\mathrm{H}^{+}$

polymerization: $x M\left(\mathrm{H}_{2} \mathrm{O}\right)_{\mathrm{n}}{ }^{\mathrm{z}+}+\mathrm{yOH}^{-}+\mathrm{aA}^{-} \rightarrow \mathrm{M}_{\mathrm{x}} \mathrm{O}_{\mathrm{u}}\left(\mathrm{H}_{2} \mathrm{O}\right)$ ${ }_{n}(\mathrm{OH})_{\mathrm{y}-2 \mathrm{u}} \mathrm{A}_{\mathrm{a}}^{(\mathrm{xz}-\mathrm{y}-\mathrm{a})+}+(\mathrm{xn}+\mathrm{u}-2 \mathrm{n}) \mathrm{H}_{2} \mathrm{O}$

Polymeric Gel (alkoxides)

hydrolysis: $\mathrm{M}(\mathrm{OR}) \mathrm{n}+\mathrm{xH}_{2} \mathrm{O} \rightarrow \mathrm{M}(\mathrm{OH})_{x}(\mathrm{OR})_{n-x}+x \mathrm{ROH}$ polymerization: $-\mathrm{M}-\mathrm{OH}+\mathrm{HO}-\mathrm{M} \rightarrow-\mathrm{M}-\mathrm{O}-\mathrm{M}-+\mathrm{H}_{2} \mathrm{O}$

\subsubsection{NUCLEATION-CRYSTALLINE GROWTH (COARSENING).}

The particle size and size distribution of the neoformed solid can be tailored in this step. In general, sol-gel methods tend to avoid the heterogeneous nucleation processes, which are greatly affected by the presence of strange inclusions (impurities or nucleation agents added in a controlled way) or unexpected hydrolysis primary products. Homogeneous nucleation let us obtain better-formed particles and a monodispersed, bimodal (and so on) distribution of the predesigned sol particles.

\subsubsection{INTERPARTICULAR AGGLOMERATION PHASE.}

The structure of the final solid is conformed. On this stage of particle ordered (gel) or disordered (precipitate) aggregation, different forces can enter into action depending on the nature of the species present.

When aqueous colloids are considered, the DLVO theory (Dejaguin, Landau, Verwey, Overbeek) offers a good explanation for the coagulation and subsequent coagule coarsening (flocculation) phenomena, attending mainly to electrostatic processes $(17,18,19)$. However, steric interactions result to be the main driving forces for the gel formation in organic colloids or in organically-protected aqueous colloids $(20,3)$.

Consequently, two different sol-gel processing alternatives can be considered as possible strategies in the synthesis of heteromorphic pigments: 
$\mathrm{Cd}\left(\mathrm{S}_{\mathrm{x}} \mathrm{Se}_{1-\mathrm{x}}\right)$,hematita en circón, hematita en sílice así como el amarillo de circona-vanadio.

Para estos casos es conveniente operar introduciendo los mineralizadores desde el principio del procesado, despreocupándose de su solubilidad siempre que su presencia no altere substancialmente el proceso de gelificación, introducir una concentración relativamente alta tanto de mineralizadores como de cromóforo, no proceder al lavado del gel (19), no precalcinar el gel y operar a relativamente bajas temperaturas en la calcinación del gel.

(II) Dada la tendencia a la metaestabilidad de los geles en nucleación homogénea, se tiene la capacidad de evitar o generar intermedios de reacción que pueden ser de alto interés para la obtención del pigmento final. Sería el caso del turquesa de vanadio en circón sin presencia de fluoruros y del amarillo de praseodimio en circón.

En el procesado de estos pigmentos, la concentración de mineralizadores y cromóforos debe minimizarse, conviene lavar y someter a precalcinación los geles, y utilizar altas temperaturas de calcinación, asismismo cuando más orgánica sea la matriz del gel, la metaestabilización es más intensa permitiendo una mayor eficiencia en el encapsulamiento (21).

\section{EXPERIMENTAL}

\subsection{El pigmento de inclusión de hematita-sílice.}

La sílice amorfa es un material de bajo coste y con un potencial como matriz huésped de pigmentos de oclusión dadas sus propiedades y, en particular, su suficiente estabilidad térmica y química frente a los vidriados así como por su facilidad de sinterización a bajas temperaturas (22). Uno de los pigmentos más estudiados con vistas a la producción de colores rojos es el de oclusión de la hematita $\left(\alpha-\mathrm{Fe}_{2} \mathrm{O}_{3}\right)$ en la matriz de sílice.

En el diagrama de fases de sílice -magnetita (23), se observa que a temperaturas por debajo de $1390^{\circ} \mathrm{C}$ las fases en equilibrio son hematita-tridimita, por debajo de $1470^{\circ} \mathrm{C}$ el polimorfo de sílice en el equilibrio es la tridimita y por encima de esta temperatura es la cristobalita. El diagrama presenta un eutéctico a $1455^{\circ} \mathrm{C}$ y $19 \%$ de $\mathrm{FeO} \cdot \mathrm{Fe}_{2} \mathrm{O}_{3}$.

Lahuerta (12), considera este pigmento similar al colorante natural "gres de Thiviers" que aunque como cualquier producto natural presenta una variación composicional importante, se trata de una mezcla de cuarzo y goetita $(\mathrm{FeO}(\mathrm{OH}))$ conteniendo del orden del $10 \%$ de $\mathrm{Fe}_{2} \mathrm{O}_{3}$. La utilización de gres de Thiviers se ha incrementado como colorante en masa de bajo coste en la industria del gres porcelánico. Lahuerta observa que con la calcinación, la goetita transita a hematita y el cuarzo a cristobalita y considera que el pigmento rojo se debe a una inclusión de hematita submicrométrica en cristobalita. Sin embargo los resultados aportados indican que los mejores tonos rojos en coloración en masa al 3\% se producen con gres de Thiviers calcinados a baja temperatura, con poca hematita y cristobalita ( a $600^{\circ} \mathrm{C}$ las medidas CIEL ${ }^{*}{ }^{*} b^{*}$ de la probeta en masa indican $\left.L^{*}=64,29, a^{*}=10,87 \mathrm{y} \mathrm{b}^{*}=7,95\right)$, mientras que calcinado a $1400^{\circ} \mathrm{C}$ con cristobalita y hematita plenamente desarrolladas los tonos son grises $\left(L^{*}=82,65, a^{*}=-1,04 \mathrm{y} \mathrm{b}^{*}=5,90\right)$. Cuando se intenta producir un gres de Thiviers sintético partiendo de $\mathrm{FeSO}_{4} \cdot 7 \mathrm{H}_{2} \mathrm{O}$, goetita o hematita como fuentes de hierro, y de LUDOX, Sílice Coloidal o cristobalita como precursores de sílice, los mejores rojos se obtienen con $\mathrm{FeSO}_{4} \cdot 7 \mathrm{H}_{2} \mathrm{O}-$ LUDOX (a* en torno a 11), sin embargo con cristobalita es muy gris. Asimismo el empleo de $\mathrm{Li}_{2} \mathrm{CO}_{3}$ como mineralizador que
(I) Attending to the high reactivity of gels in those processes activated by heterogeneous nucleation, gels can be used along with the appropriate nucleants to obtain the required crystals at low temperatures. That could apply to $\mathrm{Cd}\left(\mathrm{S}_{\mathrm{x}} \mathrm{Se}_{1-\mathrm{x}}\right)$, hematite-zircon and hematite-silica red pigments and also to vanadium-zirconia yellow pigment.

In such cases, it is highly recommendable to add the mineralizers at the first processing stage, without bothering their solubility, so long the gelation process does not become substantially affected; it is also convenient to introduce a considerably high concentration of both mineralizers and cromophore, to avoid washing the gel (19), not to make gel precalcines, and to proceed at relatively low temperatures in the firing stage.

(II) Taking profit of gel metastability when homogeneous nucleation processes are involved, it is also possible for us to avoid or to produce reaction intermediates which can eventually turn out to be crucial in order to obtain the final pigment. That would apply to the vanadium-zircon turquoise blue pigment prepared without fluorides and also to the praseodimium-zircon yellow pigment.

When the pigments are processed from gels by this alternative, mineralizer and chromophore concentrations must be minimized, and gel washing and gel precalcines along with the employment of high firing temperatures appear to be advantageous; in addition, the more organic nature of the gel matrix, the more intense becomes the metastabilization, which then results in a higher efficiency in the encapsulation (21).

\section{EXPERIMENTAL.}

\subsection{The hematite-silica inclusion pigment.}

Amorphous silica is a low-cost material with an attractive potential as a valid host matrix for developing occlusion pigments, attending to its special properties and, in particular, due to its sufficient thermal and chemical stability against most glazes, along with the fact that it can easily synterize at low temperatures (22). One of the most thoroughly studied pigments to produce red colors is that obtained by occluding hematite $\left(\alpha-\mathrm{Fe}_{2} \mathrm{O}_{3}\right)$ in the silica matrix.

In the silica-magnetite phase diagram (23), the phases hematite-trydimite are observed to be in equilibrium at temperatures below $1390^{\circ} \mathrm{C}$, trydimite is the silica polymorph stabilized below $1470^{\circ} \mathrm{C}$, while crystobalite is formed above this temperature. The diagram exhibits an eutectic at $1455^{\circ} \mathrm{C}$ with $19 \%$ of $\mathrm{FeO} . \mathrm{Fe}_{2} \mathrm{O}_{3}$

Lahuerta (12) considers this pigment to be similar to that of Thiviers gres, which though presenting an important compositional fluctuation as any other natural product, consists mainly of a mixture of quartz and goethite $(\mathrm{FeO}(\mathrm{OH}))$ with a $10 \% \mathrm{Fe}_{2} \mathrm{O}_{3}$ as average. The employment of the Thiviers gres has significantly rised being used as a low-cost mass colorant for the industry of porcelanic gres. Lahuerta observes that goethite transits to hematite and quartz to cristobalite during the calcine, and thus, suggests that the red pigment is formed as a result of the inclusion of submicronic hematite in cristobalite. However, the experimental results show that the best red hues in a 3\% mass coloration are obtained when the Thiviers gres is calcined at low temperatures, with a low hematite and cristobalite content (at $600^{\circ} \mathrm{C}$ the CIEL*a* $b^{*}$ colorimetric messures of the mass-colored pellets indicate $\mathrm{L}^{*}=64,29, \mathrm{a}^{*}=10,87$ and $\left.\mathrm{b}^{*}=7,95\right)$, while the calcines at $1400^{\circ} \mathrm{C}$ 
cataliza la transformación cuarzo a cristobalita resulta contraproducente para producir tonos rojos. En consecuencia, parece discutible la hipótesis de un pigmento basado en la protección por oclusión de hematita submicrométrica en cristobalita.

Bondioli et al. (21) estudian la síntesis convencional cerámica por reacción entre sílices coloidales de diferentes superficies específicas (entre 90 y 400 $\left.\mathrm{m}^{2} / \mathrm{g}\right)$ y fina goetita $(\mathrm{FeO}(\mathrm{OH}))$ de 10 $\mathrm{mm}$ de tamaño medio de partícula calcinando entre 900 y $1300^{\circ} \mathrm{C}$ con 4 horas de retención y con calentamiento Figura 3. Diagrama de flujo de preparación de los geles de $20^{\circ} \mathrm{C} / \mathrm{min}$. Los resultados obtenidos $\mathrm{Fe}_{2} \mathrm{O}_{3} \cdot 3 \mathrm{SiO}_{2}$.

por estos autores se pueden resumir en los siguientes puntos:

(i) el análisis termogravimétrico de las muestras indican la deshidroxilación de la goetita a hematita a $300^{\circ} \mathrm{C}$ y la eliminación de oxígeno a partir de $1200^{\circ} \mathrm{C}$ por reducción de la hematita a magnetita.

(ii) sólo a partir de $1300^{\circ} \mathrm{C}$ se observa la cristalización de cristobalita.

(iii) los test de lixiviado con $\mathrm{HCl}$ concentrado $(36 \%)$ a ebullición, indican que la solubilización de hierro, procedente de la hematita no protegida, disminuye con la superficie específica de la sílice y con la temperatura.

(iv) las coloraciones obtenidas oscilan entre $L^{*}=40-50$ y a* $=12-18$ para los polvos en el intervalo de temperaturas 1000$1200^{\circ} \mathrm{C}$ y van disminuyendo con ella, es decir se vuelven más oscuros y menos rojos.

(v) en las observaciones de microscopía electrónica de barrido de las muestras calcinadas a $1200^{\circ} \mathrm{C}$, se observa la inclusión de cristales aciculares de 0,5-2 $\mathrm{mm}$ en el seno de los aglomerados de sílice.

Bondioli et al. no hacen pruebas de esmaltado con los polvos obtenidos, por lo que no puede evaluarse la resistencia al ataque de los vidriados de estos materiales y comportarse como agentes pigmentantes efectivos.

En el presente estudio se intenta comprobar el mecanismo de sinterización-crecimiento cristalino para este pigmento, en el que las partículas coloidales de sílice y no la cristobalita son las partículas protectoras. Estas partículas se aglomeran alrededor de una hematita neoformada a $300^{\circ} \mathrm{C}$, generando grandes poros que en la sinterización se transforman por coalescencia en canales irregulares tal y como Bondioli et al. (21) observan por microscopía electrónica de barrido. whith a cristobalite and hematite full development only produce grey hues $\left(L^{*}=82,65, \quad a^{*}=-1,04\right.$ and $\left.b^{*}=5,90\right)$. When we intend to produce a syntheiic Thiviers gres using $\mathrm{FeSO}_{4} .7 \mathrm{H}_{2} \mathrm{O}$, goethite or hematite as iron precursors, and LUDOX, colloidal silica or cristobalite as silica precursors, the more intense red colors are obtained with $\mathrm{FeSO}_{4} \cdot 7 \mathrm{H}_{2} \mathrm{O}-\mathrm{LUDOX}\left(\mathrm{a}^{*}\right.$ around 11), while grey hues are obtained with cristobalite. In addition, the employment of $\mathrm{Li}_{2} \mathrm{CO}_{3}$ as mineralizer catalyzing the quartz $\rightarrow$ cristobalite transformation turns out to be disadvantageous for the red color. Consequently, the hypothesis of this red pigment being based on the occlusion of submicronic hematite in cristobalite does not seem to fit very much with the experimental results.

Bondioli et al. (21) study the conventional ceramic synthesis of the pigment by reacting colloidal silica of different specific surfaces (between 90 and $400 \mathrm{~m}^{2} / \mathrm{g}$ ) with fine goethite $(\mathrm{FeO}(\mathrm{OH}))$ of a $10 \mathrm{~mm}$ average particle size, calcining between 900 and $1300^{\circ} \mathrm{C}$ with $4 \mathrm{~h}$ soaking times and with heating gradients of $20^{\circ} \mathrm{C} / \mathrm{min}$. What these authors obtain can be summarized in the following points:

(i) TG analysis shows the dehydroxylation of goethite to hematite at $300^{\circ} \mathrm{C}$, while the oxygen loss involved in the reduction of hematite to magnetite occurs from $1200^{\circ} \mathrm{C}$.

(ii) cristobalite crystallization is only observed from $1300^{\circ} \mathrm{C}$.

(iii) leaching tests performed with $36 \% \mathrm{HCl}$ in ebullition conditions show that the iron solubilization arising from unprotected hematite decreases with the silica specific surface and also with temperature.

(iv) The colors obtained range between $L^{*}=40-50$ and $a^{*}=12$ 18 for $1000-1200^{\circ} \mathrm{C}$ fired powders and become darker (lower $L^{*}$ ) and less red (lower $\mathrm{a}^{*}$ ) at higher temperatures.

(v) SEM observations of $1200^{\circ} \mathrm{C}$ fired samples let us appreciate the inclusion of 0,5-2 $\mu \mathrm{m}$ acicular crystals in the silica agglomerates matrix.

In the present study, the synthering-coarsening mechanism occurring in this pigment is analyzed. The encapsulation or protection is performed by the silica particles instead of cristobalite; these silica particles agglomerate around the neoformed hematite at $300^{\circ} \mathrm{C}$ bringing about broad pores which in the syntering stage transform by coalescence in irregular chanels, as Bondioli et al. (21) observe by scanning electronic microscopy.

\subsection{Preparación de las muestras.}

\subsection{Sample preparation.}

Se han preparado por el procedi- TABLA I. RESULTADOS COLORIMÉTRICOS EN LAS MUESTRAS GELES miento sol-gel acuoso, según el diagra- $\mathrm{Fe}_{2} \mathrm{O}_{3} \cdot 3 \mathrm{SiO}_{2}$ :

ma de la Figura 3, dos muestras de

composición $\mathrm{Fe}_{2} \mathrm{O}_{3}$. $3 \mathrm{SiO}_{2}$ utilizando TABLE I. $\mathrm{Fe}_{2} \mathrm{O}_{3} \cdot 3 \mathrm{SiO}_{2}$ GEL SAMPLES: COLORIMETRIC RESULTS. $\mathrm{FeSO}_{4} \cdot 7 \mathrm{H}_{2} \mathrm{O}$ y $\mathrm{Fe}\left(\mathrm{NO}_{3}\right) 3.9 \mathrm{H}_{2} \mathrm{O}$ como
precursores de hierro y LUDOX ( $\mathrm{pH}$ SAMPLE
$8,32 \%$ de riqueza en $\mathrm{SiO}$ y $8,32 \%$ de riqueza en $\mathrm{SiO}_{2}$ y $\phi_{50}=3,2$ $\mu \mathrm{m})$ todos suministrados por ALDRICH (Tabla I).

Las muestras se homogeneizaron Sulphate en seco en molino de bolas, se car-
Two samples with composition $\mathrm{Fe}_{2} \mathrm{O}_{3} \cdot 3 \mathrm{SiO}_{2}$ have been prepared by the aqueous sol-gel processing (see Figure 3), using $\mathrm{FeSO}_{4} \cdot 7 \mathrm{H}_{2} \mathrm{O}$ and $\mathrm{Fe}\left(\mathrm{NO}_{3}\right) 3.9 \mathrm{H}_{2} \mathrm{O}$ as $\mathrm{Fe}$ precursors and LUDOX $\left(\mathrm{pH}=8,32 \%\right.$ of $\mathrm{SiO}_{2}$ content, and $\left.\phi_{50}=3,2 \mu \mathrm{m}\right)$, all of them supplied by ALDRICH (Table I).

The powder formulations were dry homogenized in ball mills, and 
garon en crisoles silicoaluminosos compactando el polvo manualmente y se calcinaron a la temperaturas de $600^{\circ} \mathrm{C}$ y $800^{\circ} \mathrm{C}$ con $2 \mathrm{~h}$ de retención y 4 horas de subida hasta esta temperatura con velocidad de calentamiento constante.

La muestra a partir de $\mathrm{FeSO}_{4} \cdot 7 \mathrm{H}_{2} \mathrm{O}$ no gelificó, obteniéndose un coprecipitado verdoso a $\mathrm{pH}$ 9. La muestra con nitrato genera un gel rojo homogéneo a $\mathrm{pH} 3$. El color de las muestras crudas es marrón naranja.

\subsection{Métodos de caracterización empleados.}

\subsubsection{DIFRACCIÓN DE RAYOS X (DRX)}

Se han seguido las fases cristalinas por difracción de rayos $X$ por el método del polvo orientado al azar de las muestras calcinadas en el intervalo entre 10 y $70^{\circ} 2 q$. Los difractogramas se obtuvieron en un difractómetro Siemens D-500 con radiación $\mathrm{Cu} \mathrm{K}$ filtrada con $\mathrm{Ni}$ y con velocidad del goniómetro de $0,05^{\circ} 2 \theta$ / segundo.

\subsection{2.- ESMALTACIÓN Y MEDIDAS COLORIMÉTRICAS}

Los pigmentos cerámicos se esmaltaron con un porcentaje de producto colorante del $5 \%$ en el esmalte. La fórmula Seger de la frita del esmalte que se utiliza en revestimiento cerámico es: then calcined in $\mathrm{Si}-\mathrm{Al}$ crucibles, being the powder compacted manually. Calcines were carried out at $600^{\circ} \mathrm{C}$ and $800^{\circ} \mathrm{C}$ with a $4 \mathrm{~h}$ constant heating and a $2 \mathrm{~h}$ soaking time at the maximum temperature.

The sulphate-containing sample did not produce a gel, but a greenish coprecipitate at a $\mathrm{pH}=9$. The sample with iron nitrate gave rise to an homogeneous red gel at a $\mathrm{pH}=3$. The color of raw powder samples was brown-orange.

\subsection{Sample characterization techniques.}

\subsubsection{X-RAY DIFFRACTION (XRD).}

The evolution of crystalline phases in the calcined samples was followed by XRD using the conventional powder method (randomly oriented) between 10 and $70{ }^{\circ} 2 \theta$. The XRD patterns were obtained with a D-500 Siemens diffractometer with $\mathrm{Ni}$ filtered $\mathrm{CuK}_{\mathrm{a}}$ radiation and with a goniometer speed of $0.05^{\circ} 2 \theta / \mathrm{s}$ ( $1 \mathrm{~s}$ of counting time per step).

\subsection{2.- ENAMELLING AND COLORIMETRIC MEASURES.}

The fired pigments were enamelled with a fritted glaze adding a 5\% of color in the glaze. The Seger formula of the fritted glaze is as follows:

\begin{tabular}{|c|c|c|c|c|c|}
\hline $\mathrm{K}_{2} \mathrm{O}$ & 0,106 & & & & \\
\hline $\mathrm{Na}_{2} \mathrm{O}$ & & & & \multirow{3}{*}{$\mathrm{SiO}_{2}$} & \multirow{3}{*}{1,972} \\
\hline $\mathrm{MgO}$ & - & $\mathrm{Al}_{2} \mathrm{O}_{3}$ & 0,323 & & \\
\hline $\mathrm{CaO}$ & 0,565 & & & & \\
\hline $\mathrm{ZnO}$ & 0,329 & & & & \\
\hline
\end{tabular}

molino de bolas. Para ello se añadió un $60 \%$ de agua manteniendo el molino a $800 \mathrm{rpm}$ durante 20 minutos. Ell polvo se decantó y se volvió a lavar con agua añadiendo $200 \mathrm{~mL}$ de agua a los $100 \mathrm{~g}$ de polvo, agitando vigorosamente la suspensión y recogiendo el polvo por decantación. Por último los polvos micronizados y lavados se secaron en estufa a $110^{\circ} \mathrm{C}$.

La frita y el color se homegeneizaron en un molino de bolas utilizando aproximadamente un $40 \%$ de agua y un 5\% de caolín. La barbotina así obtenida se depositó a lengua sobre un soporte cerámico de monoccocción de pasta roja con engobe. El conjunto fue cocido en horno Nannetti a $1085^{\circ} \mathrm{C}$ con ciclo rápido de 45 minutos de duración.

Las medidas colorimétricas se llevaron a cabo según la normativa CIE$\mathrm{L}^{*} \mathrm{a}^{*} \mathrm{~b}^{*}$ (CIE, Comission International de l'Eclairage). Los valores de $L^{*} a^{*} b^{*}$ son tres parámetros o ejes colorimétricos: el eje de claridad de la muestra ( $\mathrm{L}^{*}=0$ para muestra negra ideal (absorción total) y 100 para muestra blanca ideal (reflexión total), el eje a* ( eje de Figura 4. DRX: (a) muestra con $\mathrm{FeSO}_{4} \cdot 7 \mathrm{H}_{2} \mathrm{O}$ a $800^{\circ} \mathrm{C}$, (b) verde $\rightarrow$ rojo) y el eje $b^{*}$ ( eje de azul $\rightarrow$ amarillo ).

Figure 4. XRD: (a) sulphate $800^{\circ} \mathrm{C}$, (b) nitrate $800^{\circ} \mathrm{C}$.

\begin{tabular}{|c|c|c|c|c|c|}
\hline $\mathrm{K}_{2} \mathrm{O}$ & 0,106 & & & & \\
\hline $\mathrm{Na}_{2} \mathrm{O}$ & - & & & \multirow{3}{*}{$\mathrm{SiO}_{2}$} & \multirow{3}{*}{1,972} \\
\hline $\mathrm{MgO}$ & - & \multirow[t]{3}{*}{$\mathrm{Al}_{2} \mathrm{O}_{3}$} & \multirow[t]{3}{*}{0,323} & & \\
\hline $\mathrm{CaO}$ & 0,565 & & & & \\
\hline $\mathrm{ZnO}$ & 0,329 & & & & \\
\hline
\end{tabular}

Previously, the powders had been micronized and washed in a ball-mill. With this aim a $60 \%$ of water was added and the ball-mill was maintained at $800 \mathrm{rpm}$ during 20 minutes. The mixture was decanted and washed once again adding $200 \mathrm{~mL}$ of distilled water to the $100 \mathrm{~g}$ of powder, stirring vigorously the suspension and collecting the powder also by decanting the supernatant liquid. These micronized and washed powders were finally dried in a furnace at $110^{\circ} \mathrm{C}$ before being enameled.

The frit and the color were ballmilled adding water (40\% approx.) and caolin (5\% approx.). The as obtained barbotine was dip-coated onto engobbed red-clay single-firing ceramic biscuits. A single firing of the enamel-ceramic biscuit set was then performed in a Nannetti furnace at $1085^{\circ} \mathrm{C}$ with a $45 \mathrm{~m}$ fast-firing scheme.

The colorimetric measures were carried out following the CIE-L*a* $b^{*}$ recommendations (CIE, Comission International de 1'Eclairage). The $\mathrm{L}^{*} \mathrm{a}^{*} \mathrm{~b}^{*}$ values are three parameters or colorimetric axis: the sample lightness axis $\left(\mathrm{L}^{*}=0\right.$ for an ideal dark sample -total absorption-, and $\mathrm{L}^{*}=100$ for an 


\subsubsection{MICROSCOPÍA ÓPTICA Y ELECTRÓNICA DE BARRIDO}

Las muestras fueron observadas mediante un microscopio pancromático Olympus 2000 dotado con sistema de microfotografía. Asimismo las muestras previamente sombreadas con grafito, se observaron en un microscopio electrónido de barrido (SEM) suministrado por Leyca dotado con sistema de análisis de dispersión de energías (EDX) de Oxford.

\section{RESULTADOS Y DISCUSIÓN.}

En la figura 4 se presentan los difractogramas de rayos $\mathrm{x}$ tanto de la muestra con sulfato de hierro (II) calcinada a $800^{\circ} \mathrm{C}$ (Fig 4.a) como la nitrato de hierro (III) tratada a $800^{\circ} \mathrm{C}$ (Fig. 4.b). En las muestras crudas sólo son apreciables picos de difracción asociables a sulfato amónico en la muestra obtenida a partir de $\mathrm{FeSO}_{4} .7 \mathrm{H}_{2} \mathrm{O}$. A $600^{\circ} \mathrm{C}$ los polvos no presentan picos de difracción. A $800^{\circ} \mathrm{C}$ en la muestra obtenida con sulfato de hierro (II) no se detectan los picos de difracción de la hematita, en cambio en la muestra nitrato se observan picos asociables a esta fase, así como una banda ancha de difracción centrada a $22^{\circ} 2 \Theta$ asociada a cristobalita. Por tanto, en la muestra obtenida con sulfato de hierro (II), la hematita estaría mejor protegida y en forma de partículas más pequeñas si asumimos un modelo de oclusión de hematita submicrométrica por sílice no cristalina. Las posibilidades de encapsulado serían inferiores en la muestra a partir de nitrato de hierro (III) calcinada a $800^{\circ} \mathrm{C}$ con hematita desprotegida y detectable por difracción de rayos $X$ y con una incipiente cristalización de cristobalita.

La observación por microscopía óptica de las muestras indica una coloración rojo naranja de las partículas calcinadas a $600^{\circ} \mathrm{C}$ y rojo oscuro las de $800^{\circ} \mathrm{C}$, las muestras de $600^{\circ} \mathrm{C}$ presentan una menor fracción de partícula coloreadas, que se hace evidente sobretodo en la muestra con nitrato, dond abundan las partículas de sílice incoloras. Asimismo a $800^{\circ} \mathrm{C}$ la sinterización del material se observa más avanzada con monolitos grandes y oscuros. La forma de las partículas es irregular con bordes puntiagudos, típica de un vidrio molturado. En las muestras pueden observarse al microscopio óptico partículas rojas de hematita ocluidas en la partícula transparente de sílice.

Las muestras esmaltadas al 5\% en el esmalte de monoporosa cristalina, generan coloraciones rosa claro con las muestras a $600^{\circ} \mathrm{C}$. Las muestras $800^{\circ} \mathrm{C}$ presentan un color rosa relativamente intenso, destacando el rosa más limpio de la muestra obtenida con sulfato de hierro (II). En la Tabla I se presentan las medidas CIEL*a* $b^{*}$ de estas muestras: de acuerdo con la percepción visual, la
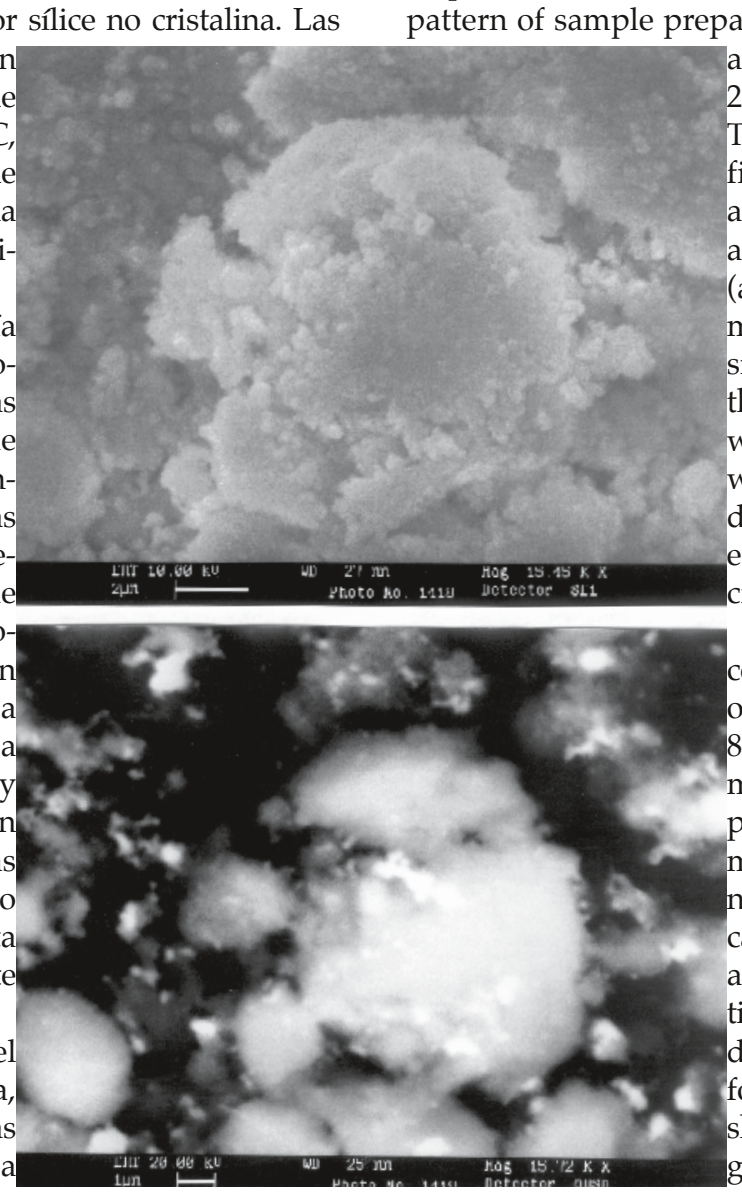

Figura 5. Micrografías electrónicas de barrido muestra nitrato $800^{\circ} \mathrm{C}$ : (a) detector de electrones secundarios, (b) detector de electrones retrodispersados.

Figure 5. SEM micrographs of $800^{\circ} \mathrm{C}$-fired nitrate sample: (a) secondary electron detector, (b) backscattering electron detector. ideal white sample -total reflection-), the $\mathrm{a}^{*}$ axis (goes from green -negative- to red -positive-), and the $b^{*}$ axis (goes from blue -negative- to yellow -positive-).

\subsubsection{OPTIC AND SCANNING ELECRONIC}

The samples were observed by means of a planchromatic Olympus 2000 microscope equipped with a micro-photographic attachment. Samples previously carbon-sputtered were also observed wit a Leyca Scaning Electronic Microscope (SEM) equipped with an Energy Dispersion X-ray (EDAX) attachment by Oxford University.

\section{RESULTS AND DISCUSSION.}

Figure 4 shows the XRD patterns of both $800^{\circ} \mathrm{C}$ fired samples, prepared either with iron(II) sulphate (Fig 4.a) or with iron(III) nitrate (Fig. 4.b). With regard to raw samples, only $\mathrm{XRD}$ peaks associated to ammonium sulphate can be observed in the sample prepared from $\mathrm{FeSO}_{4} \cdot 7 \mathrm{H}_{2} \mathrm{O}$. At $600^{\circ} \mathrm{C}$, the powders do not present XRD peaks. At $800^{\circ} \mathrm{C}$, hematite diffraction peaks are not observed in the sample with iron(II) sulphate, while these hematite peaks are to be found in the pattern of sample prepared from iron(III) nitrate, along with a broad diffraction band centered at $22^{\circ} 2 \Theta$ associated to cristobalite. Therefore, and attending to the $800^{\circ} \mathrm{C}$ fired powders, the hematite phase appears to be much better protected and consisting of smaller particles (assuming an occlusion model of submicronic hematite by non-crystalline silica) when using iron(II) sulphate than when using iron(III) nitrate, in which the encapsulating efficiency would be lower, remaining XRDdetectable unprotected hematite, and exhibiting an incipient cristobalite crystallization.

Sample observations by optic microscopy indicate a red-orange coloration of the $600^{\circ} \mathrm{C}$-fired particles, while the $800^{\circ} \mathrm{C}$-fired powders result to be red; moreover, a lower fraction of colored particles is presented at $600^{\circ} \mathrm{C}$, which is more evident in the sample with iron nitrate, where abundant uncolored silica particles are observed. Furthermore, a more advanced material synterization is observed at $800^{\circ} \mathrm{C}$, with big, dark monoliths. Particle shape is found to be rather irregular, and with sharp edges, quite typical of a molten glass. Red particles of hematite occluded by the transparent silica can also be observed in the optic microscope.

Samples 5\%-enamelled with the single-firing transparent glaze produce light pink colorations at $600^{\circ} \mathrm{C}$, while a relatively intense pink color 
claridad $L^{*}$ disminuye de 70 a 60 al aumentar la temperatura de calcinación (61 en la muestra obtenida con nitrato de hierro (III)), asimismo el parámetro rojo $\mathrm{a}^{*}$ aumenta dos puntos, hasta 13 en la muestra obtenida con sulfato de hierro (II).

En la figura 5 se presentan micrografías electrónicas de los polvos micronizados La imagen topográfica con electrones secundarios (Fig.5-a), indica una microestructura de agregados de gránulos muy pequeños, del orden de $200 \mu \mathrm{m}$ muy sinterizados en el centro del agregado. La observación con detector de electrones retrodispersados del mismo campo (Fig. 5 -b) indica acumulaciones de forma irregular de alto contraste y de tamaño en torno a $500 \mu \mathrm{m}$. Los análisis por energías de dispersión de rayos $x(E D X)$ de las partículas externas, que alcanzan tamaños mayores, en torno a $1 \mu \mathrm{m}$ muchas veces, indica que se trata de hematita libre $\left(\mathrm{Fe}_{2} \mathrm{O}_{3}\right.$ del orden del $\left.76 \%\right)$. Por el contrario las partículas constituyentes de los agregados indican un aumento de hierro medido por SEM/EDX a medida que se aumenta el margen de aumentos del microscopio (de un $27 \%$ a $\times 15.000$ hasta un $34 \%$ a $\times 140.000$ ).

Estos resultados evidencian una oclusión de hematita del orden de $200 \mu \mathrm{m}$ en el seno de gránulos sinterizados del mismo orden de tamaño, corroborándose el modelo de sinterización-crecimiento cristalino en este sistema.

Los análisis SEM/EDX globales repetidos en las muestras calcinadas a $800^{\circ} \mathrm{C}$ indican un contenido de $\mathrm{Fe}_{2} \mathrm{O}_{3}$ ligeramente superior en la muestra obtenida con nitrato de hierro(III) (27,5\% frente a $26 \%$ en la muestra con sulfato) de acuerdo con la menor claridad $L^{*}$ de la muestra. Sin embargo la eficiencia del encapsulado es inferior en esta muestra, con más hematita externa anteriormente mencionada, lo que implica un parámetro $\mathrm{a}^{*}$ rojo inferior.

La descomposición del nitrato a baja temperatura (en torno a $\operatorname{los} 350^{\circ} \mathrm{C}$ ) genera hematita a estas temperaturas. Por el contrario, el sulfato elimina seis moléculas de agua a $90^{\circ} \mathrm{C}$, la séptima a $300^{\circ} \mathrm{C}$ y descompone generando hematita en la atmósfera oxidante utilizada en el horno, en torno a $\operatorname{los} 600^{\circ} \mathrm{C}$. La presencia de hematita desde $\operatorname{los} 300^{\circ} \mathrm{C}$, permite que la fase de crecimiento cristalino o "coarsening" de sus partículas sea más amplia por lo que la oclusión en las muestras obtenidas con nitrato de hierro(III) es menos efectivo y con tamaños grandes de hematita, como se aprecia en microscopía óptica, donde también se pueden observar microcristales de color rojo intenso de hematita de unos 5-6 um junto a las partículas coloreadas de sílice.

\section{CONCLUSIONES.}

Utilizando el procesado sol-gel en medio acuoso, es posible controlar las condiciones para obtener una buena eficiencia de encapsulado en los pigmentos cerámicos de naturaleza heteromórfica. La elección de los precursores en la síntesis así como las condiciones de precipitación-gelificación son fundamentales. En el caso estudiado de oclusión de hematita en sílice, se han conseguido mediante estas técnicas, altos niveles de encapsulado de hematita en sílice capaces de colorear con adiciones al 5\% matrices vítreas de monococción porosa cocidas en ciclo rápido a $1.085^{\circ} \mathrm{C}$. La muestra obtenida a partir de sulfato de hierro (II) heptahidrato presenta las coloraciones rosa más limpias con $\mathrm{L}^{*}-\mathrm{a}^{*}-\mathrm{b}^{*}=66-13-13$ en adiciones del $5 \%$ en la citada matriz vítrea. are presented by the $800^{\circ} \mathrm{C}$-fired samples, outstanding the cleaner pink color of the sample prepared from iron(II) sulphate. The CIEL ${ }^{*}{ }^{*} b^{*}$ parameters measured in these samples can be found in Table I: in accordance with the visual perception, the lightness $L^{*}$ decreases from 70 to 60 when rising the firing temperature (61 in the sample prepared from iron(III) nitrate), and the red parameter $\mathrm{a}^{*}$ is found to rise in two units up to 13 in the sample with iron(II) sulphate.

Electronic micrographs of the micronized fired powders are presented in Figure 5. The topographic secondary electron image (Fig.5-a), show a microstructure consisting of very small aggregated granules (ranging $200 \mu \mathrm{m}$ ), which in addition appear to be highly synthered in the aggregate center. The observation with the back-scattering electron emission detector of the same field (Fig. 5-b) let us appreciate high-contrast, irregular-formed accumulations around $500 \mu \mathrm{m}$ sized. EDX analyses of the bigger external particles (mostly around $1 \mu \mathrm{m}$ ), let us associate this particles to free hematite $\left(\mathrm{Fe}_{2} \mathrm{O}_{3}\right.$ weight percentage around $76 \%$ ). On the contrary, aggregate-forming particles exhibit a much lower EDAX-measured iron content, which in turn results to rise with the microscope magnification (from $27 \%$ at a 15,000 magnification up to $34 \%$ at a 140,000 magnification). This results evidence an occlusion of hematite $\sim 200 \mu \mathrm{m}$ sized by equally-sized, synterized granules, in agreement with the synthering-coarsening mechanism proposed for this system.

The repeated global SEM/EDX analyses performed with $800^{\circ} \mathrm{C}$-fired samples show a slightly higher $\mathrm{Fe}_{2} \mathrm{O}_{3}$ content in the sample obtained with iron(III) nitrate (27,5\% against $26 \%$ in the sulphate sample) in accordance with its lower clarity $\left(\mathrm{L}^{*}\right)$. Nevertheless, the encapsulation efficiency is inferior in this sample, with higher amounts of external free hematite, as already mentioned, resulting in a lower $\mathrm{a}^{*}$ red parameter.

The low-temperature decomposition of the iron nitrate (around $350^{\circ} \mathrm{C}$ ) gives rise to hematite at these temperatures. On the contrary, the hydrated iron sulphate loses six water molecules at $90^{\circ} \mathrm{C}$ and the seventh at $300^{\circ} \mathrm{C}$, decomposing to produce hematite in the oxidant furnace atmosphere at about $600^{\circ} \mathrm{C}$. The earlier presence of hematite from $300^{\circ} \mathrm{C}$ allows the process of crystalline growth or "coarsening" of the hematite particles to progress much further in the samples obtained with iron(III) nitrate, which in turn results in a less efficient occlusion and in bigger hematite particles, as observed by optic microscopy, where intense red-colored hematite micro-crystals (5-6 $\mu \mathrm{m})$ can also be observed along with the colored silica particles.

\section{CONCLUSIONS.}

The aqueous sol-gel processing proves to be a good synthesis method to control the conditions needed for obtaining a good efficiency in the encapsultion of ceramic pigments of heteromorphic nature . The election of the appropriate synthesis precursors, as well as the precipitation-gelation conditions appear to be of the utmost importance. In the studied case of hematite occlusion in silica, high efficiencies in the hematite encapsulation have been obtained by means of these preparation techniques, succeeding in the coloration with a $5 \%$ addition of porous single-firing glassy matrixes fired at $1.085^{\circ} \mathrm{C}$ in a fast-firing schedule. The purer pink color $\left(\mathrm{L}^{*}-\mathrm{a}^{*}-\mathrm{b}^{*}=66-13-13\right)$ has been obtained in the sample prepared from iron(II) sulphate with a 5\% addition to this glassy matrix. 


\section{BIBLIOGRAFIA / REFERENCES}

1. Weyl W.A., Marboe E. Ch., "The Constitution of Glasses", p. 292, Interscience Pub., John Wiley, New York, 1969.

2. Carda J., Tesis Doctoral, , Universitat de València, Diciembre 1990.

3. Monrós G., Tesis Doctoral, Universitat de València, Abril 1991.

4. J. Badenes, "Pigmentos amarillos de praseodimio", Tesis de Licenciatura, Universitat Jaume I, Septiembre 1994.

5. White M.G., "Heterogeneous catalysis", p.12, Prentice-Hall , London,1990.

6. Shaw K., Ceramic Colours and Pottery Decoration, p.54 McLaren and Sons Ltd., London, 1968.

7. Lambíes V., Rincón J. Ma., Study of the Mechanism of Formation of a ZirconCadmium Sulphoselenide Pigment, Trans. J. Br. Ceram. Soc., 80 105-108 (1981).

8. Batchelor R.W., "Modern Inorganic Pigments",Trans. J. Br. Ceram. Soc., 73 297-301 (1974)

9. Chi-Hang Li, Eppler D.A, Eppler R.A., “Iron Zircon Pigments”, Ceram Eng. Sci. Proc. 13[1-2] 109-118 (1992).

10. Beltrán J., Guillem C. , Lambies V., “Obtención de pigmentos rojos de SSeCd", Bol. Soc. Esp. Ceram. Vidr., 16291 (1977).

11. Eppler R.A., "Kinetics of formation of an Iron-Zircon Pink color, J. of Amer. Ceram. Soc. 62[1] 247-249 (1979).

12. Lahuerta J., Tesis Doctoral, Universitat de València, Junio 1993.

13. Tartaj P., Gonzalez-Carreño T., Serna C.J., Ocaña M., "Iron Zircon Pigments Prepared by Pyrolysis of Aerosols", J. of Solid State Chemistry, 128 102-108 (1997).
14. Llusar M., "Optimización medioambiental de la síntesis de pigmentos cerámicos: aplicación de métodos sol-gel", Tesis Doctoral, Dpto. de Química Inorgánica y Orgánica, Universitat Jaume I, Castellón, Septiembre 1998.

15. Villegas M.A., “Aerogeles", Bol. Soc. Esp. Ceram. y Vidr., 29[53] 15-329 (1990).

16. Pierre A.C., Sol-Gel Processing of Ceramic Powders, Ceram. Bull. 70 12811288, (1991)

17. Hiemenz P.C., Principles of Colloid and Surface Chemistry, p. 218, Marcel Dekker, New York, 1977.

18. Hunter R.J., "Zeta Potential in Colloid Science”, Academic Press, New York, 1981.

19.Heller W., "Ordered and Disordered Aggregation of Colloidal particles and Macromolecules", pp 153-207, en Polymer Colloids 2, ed. por R.M. Fitch, Plenum New York, 1980.

20. Monrós G., Carda J., Tena M.A., Escribano P., Badenes J., Cordoncillo, E., "Spinels from Gelatine Protected Gels", J. Mat. Chem. 5[53] 85-90 (1995).

21. Bondioli F., Ferrari A.M., Leonelli C., Manfredini T., "Syntheses of $\mathrm{Fe}_{2} \mathrm{O}_{3}$ Silica Red Inorganic Inclusion Pigments for ceramic Applications", Mat. Res, Bull., 33 723-729 (1998).

22. Monrós G., Carda J., Tena M.A. , Escribano P., Alarcón J., “Nuevos procesos en la fabricación de pigmentos cerámicos", p. 39, ed. Faenza Editrice y Sdad. Esp. de Ceram. y Vidr., Eds. Científicos J. Ma. Rincón, J. Carda, J. Alarcón. 1991

23. Phase Diagrams for ceramists, Fig. 87. Vol. I. 